\title{
Scuds (Gammaridae) and Darters (Percidae) Dominate Aquatic Communities in a Stream Exhibiting Levels of Specific Conductance Exceeding 4,000 $\mu \mathrm{S} / \mathrm{cm}$
}

\author{
William Griffiths Kimmel, David Gordon Argent* \\ Department of Biological and Environmental Sciences, California University of Pennsylvania, California, USA \\ Email address: \\ kimmel@calu.edu(W. G. Kimmel), argent@calu.edu(D. G. Argent) \\ ${ }^{*}$ Corresponding author

\section{To cite this article:} \\ William Griffiths Kimmel, David Gordon Argent. Scuds (Gammaridae) and Darters (Percidae) Dominate Aquatic Communities in a Stream \\ Exhibiting Levels of Specific Conductance Exceeding 4,000 $\mu \mathrm{S} / \mathrm{cm}$. International Journal of Environmental Monitoring and Analysis. \\ Vol. 6, No. 2, 2018, pp. 47-52. doi: 10.11648/j.ijema.20180602.12
}

Received: April 23, 2018; Accepted: May 5, 2018; Published: May 28, 2018

\begin{abstract}
Surface and underground extraction of coal has degraded many landscapes throughout the Appalachian region of the United States. The deleterious effects on steam biota of untreated acidic drainages high in heavy metals from active and abandoned sites have been well-documented. Mitigation strategies frequently include the addition of strong neutralizing agents in order to elevate $\mathrm{pH}$ and precipitate toxic metals. The resulting effluents exhibit high concentrations of sulfates, chlorides, carbonates, and other ions which can markedly raise the specific conductance of receiving streams. However, the impacts of such inputs on stream ecosystems are not well-studied. This study documents one such case, Whiteley Creek, a Monongahela River tributary in southwestern Pennsylvania, which receives treated effluents producing in-stream conductivity values in excess of $4,000 \mu \mathrm{S} / \mathrm{cm}$. Fish and macroinvertebrate communities were sampled at ten sites from its headwaters to its Monongahela River confluence exhibiting conductivity values ranging from 2,400 - 5,400 $\mu \mathrm{S} / \mathrm{cm}$. Specific conductance showed no relationship to taxonomic richness of either community; however fish abundance declined with increasing conductivity, while macroinvertebrates increased. Extant communities dominated by tolerant taxa resulted in low macroinvertebrate and fish Indices of Biotic Integrity scores indicative of community stress. This study underscores the importance of biomonitoring and bioassessment of streams receiving effluents of chemically-treated acid mine drainages.
\end{abstract}

Keywords: Macroinvertebrates, Fish, Specific Conductance

\section{Introduction}

Discharges from the extraction of anthracite and bituminous coal deposits have impacted 4,022 $\mathrm{km}$ of streams in the Commonwealth of Pennsylvania, constituting its single largest non-point source of pollution [1]. Bituminous coalmining operations such as those occurring in southwestern Pennsylvania can produce acidic or alkaline discharges containing elevated concentrations of suspended solids, metals, and sulfates [2]. Both acid mine drainage (AMD) or net alkaline mine drainage (NAMD) may be produced during surface and underground mining operations depending on local geologic conditions [3]. Acid mine drainage is characterized by depressed levels of $\mathrm{pH}$, total alkalinity/total acidity $<1$ and high levels of dissolved metals such as iron, aluminum, and manganese which can decimate aquatic life in receiving streams. By contrast, NAMD discharges feature circumneutral $\mathrm{pH}$ levels, total alkalinity/total acidity $>1$, and metals in suspension or sediment which create the familiar orange colored "yellow-boy" of receiving streams. The two also differ in their effects on aquatic life with AMD producing toxic physiological conditions often resulting in the absence of fish and macroinvertebrate communities; while NAMD results in ferric hydroxide $\left(\mathrm{FeOH}_{3}\right)$ precipitates which cover benthic habitats - a physical constraint to aquatic life [4, 5].

While AMD often produces sterile streams, those impacted by NAMD may harbor extant fish and macroinvertebrate communities frequently depauperate in taxonomic richness and density [6-8]. Acid mine drainage may transform into 
NAMD effects in a receiving stream when encountering oxygen and limestone strata which elevates $\mathrm{pH}$ and precipitates metals. The federal Surface Mining Control and Reclamation Act of 1977 (P. L. 95-87) has resulted in improved mining practices and remediation of increasing numbers of abandoned mine sites. However, the long history of coal extraction in Pennsylvania has left a legacy of more than $4,000 \mathrm{~km}$ of streams with absent or depauperate aquatic communities [1].

Treated drainages from active mining and preparation facilities along with brines from oil and gas well development $[9,10]$ can also impair lotic ecosystems by elevating ambient concentrations of total dissolved solids (TDS) and salinity. Much of the current focus of the impacts of wastewater from energy extraction has centered on fracking of natural gas from shale deposits. Such wastewater is high in brines which can produce extremely high levels of specific conductance. Contamination of Dunkard Creek, a Monongahela River tributary in Pennsylvania, resulted in stream conductivity of 5,000 to $50,000 \mu \mathrm{S} / \mathrm{cm}$ [11]. This triggered a bloom of golden algae and its toxic metabolites which decimated fish, amphibians, and macroinvertebrates along $68 \mathrm{~km}$ of stream [11]. In order to protect aquatic life, the US Environmental Protection Agency (USEPA) has recommended a $300 \mu \mathrm{S} / \mathrm{cm}$ benchmark for impairment of receiving waters below discharges of elevated conductivity in the Central Appalachian Region of the United States [12].

The impacts of treated mine drainages on receiving streams has been less well-documented. The treatment of mine drainages, depending on type, has been undertaken by a variety of remediation strategies broadly categorized into "active" and "passive" treatments with the former employing the direct addition of neutralizing chemicals including strong alkaline agents (e.g., $\mathrm{NaOH}, \mathrm{CaO}, \mathrm{Ca}\left(\mathrm{OH}_{2}\right)$ ) to neutralize acidity and precipitate metals [13, 14]; and the latter directing the inputs into limestone beds and/or constructed wetlands to precipitate metals $[1,15,16]$. The chemical additives utilized in $\mathrm{pH}$ modification, metal precipitation, and sulfur oxidation may produce alkaline effluents high in TDS resulting in elevations of specific conductance in receiving streams well above the USEPA $300 \mu \mathrm{S} / \mathrm{cm}$ benchmark $[17,18]$. Research into the effects of treated mine drainages high in specific conductance and total dissolved solids (TDS) on aquatic communities have been limited and somewhat equivocal. Metrics such as species richness and diversity were not reliable indicators of macroinvertebrate community stress resulting from elevated TDS and specific conductance [19]. Pond et al. [20] determined adverse effects on aquatic communities at levels in excess of $500 \mu \mathrm{S} / \mathrm{cm}$. However, chemical and biological assessments of a major Monongahela River tributary in Pennsylvania, the South Fork of Tenmile Creek, documented extant fish and macroinvertebrate communities at levels of specific conductance exceeding $1,000 \mu \mathrm{S} / \mathrm{cm}[17,18]$.

The objective of this study was to assess the status of fish and macroinvertebrate communities in a stream impacted by extremely high levels of specific conductance, $\mathrm{pH}$, and total alkalinity as a result of active treatment of AMD in its headwaters by strong alkaline agents.

\section{Methods}

\subsection{Description of Study Area}

Whiteley Creek, a $3^{\text {rd }}$ order tributary of the Monongahela River located in Greene County southwestern Pennsylvania, is designated as a Warm-Water Fishery (WWF) by the Pennsylvania Department of Environmental Protection [21] (Figure 1).

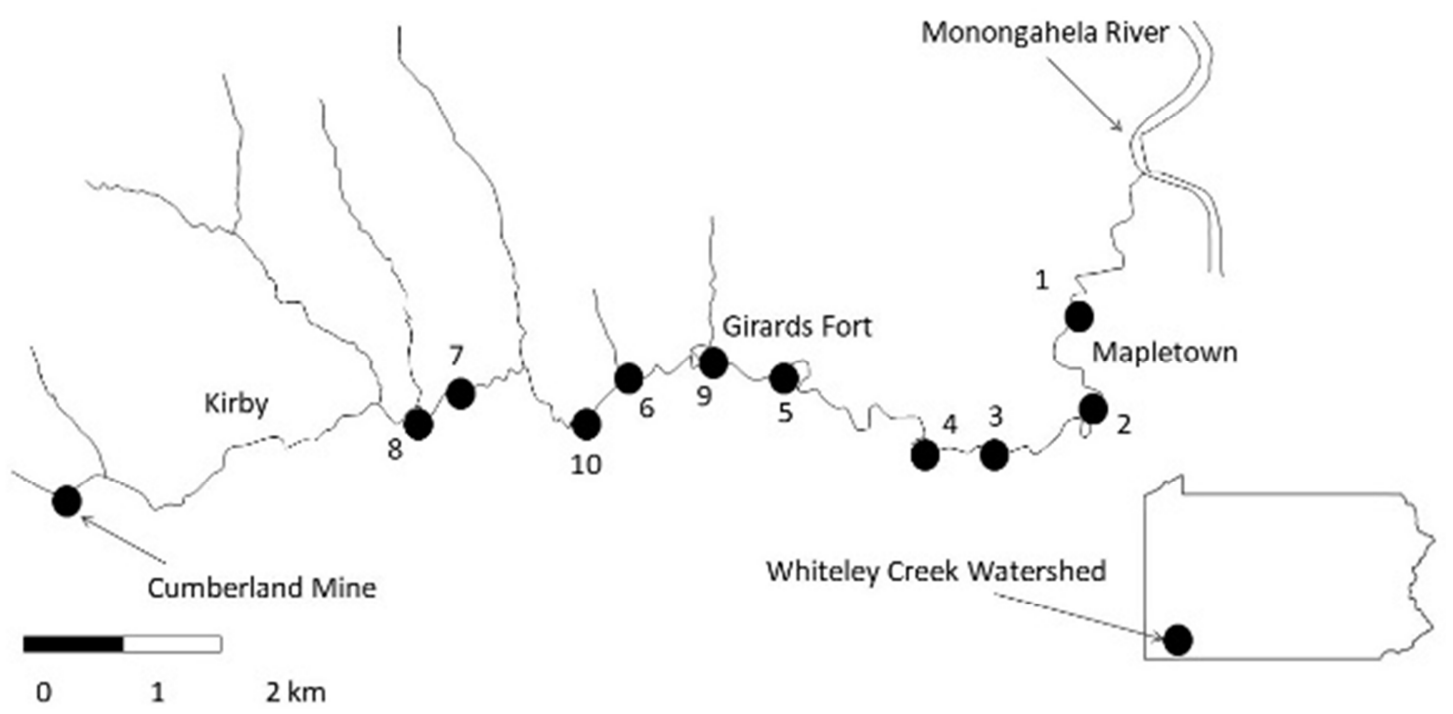

Figure 1. Sampling stations along Whiteley Creek.

Land use within the $140 \mathrm{~km}^{2}$ watershed includes agriculture, small rural communities, and coal extraction. The largest influence here is the Cumberland coal processing and treatment facility which encompasses approximately 40 ha of its headwaters. The mine drainage treatment process here relies on the addition of caustic 
alkaline agent (s) to elevate $\mathrm{pH}$ and precipitate metals with the resulting effluents discharged directly into Whiteley Creek.

\subsection{Sampling and Data Analyses}

Ten sampling stations were located approximately 2.0 $\mathrm{km}$ apart spanning nearly the entire $26 \mathrm{~km}$ watercourse from headwaters to its confluence with the Monongahela River. During the summer of 2016, measurements of temperature $\left({ }^{\circ} \mathrm{C}\right), \mathrm{pH}$, and specific conductance $(\mu \mathrm{S} / \mathrm{cm})$ were performed in the field at each sampling station using a pH Testr3+ (Oakton Instruments) and a YSI (Yellow Springs Instruments) Model 33 S-C-T meter. A separate sample was returned to the laboratory at California University of Pennsylvania (CalU) for analysis of total alkalinity $\left(\mathrm{mg} / \mathrm{l}\right.$ as $\left.\mathrm{CaCO}_{3}\right)$ by standard titration with $\mathrm{N} / 50$ sulfuric acid.

Fish were collected by one-pass back-pack electrofishing over a $100-\mathrm{m}$ reach at each site, and identified, enumerated, and released in the field. Due to the very high levels of specific conductance, adjustment of voltage and amplitude of the electrofisher were necessitated at each station to ensure comparable sampling efficiency. The collection and handling of fish complied with the California University of Pennsylvania's Institutional Animal Care and Use Committee guidelines. Macroinvertebrates were sampled using a one- $\mathrm{m}^{2}$ kick-net according to protocols established by the Pennsylvania DEP [22]. Three samples at each site were pooled to form a station composite, preserved in $70 \%$ isopropyl alcohol, and returned to the laboratory at CalU for identification to the lowest practicable taxonomic level and enumeration. Simple linear regression analysis was performed to examine the relationships among specific conductance and fish/macroinvertebrate abundance and taxonomic richness. Relationships were considered significant if the p-value $<$ 0.05 .

In order to assess biotic communities over the entire sampling reach, data from all stations were pooled for tallies of species richness, abundance, and computation of fish and macroinvertebrate Indices of Biotic Integrity (IBI). Indices of Biotic Integrity for fish and macroinvertebrate communities were those developed by Kimmel and Argent [7] and "Pennsylvania's wadeable, freestone, riffle-run streams" [22], respectively. Both employ analyses of multiple metrics to arrive at numerical total scores indicative of community health. The Fish IBI is comprised of 10 metrics and scores range from 2 ("very poor") to 48-50 ("excellent"). The Pennsylvania DEP IBI [22] integrates seven individual metrics into a scoring range from $\leq 43$ ("impaired") to $\geq 43$ ("attaining").

\section{Results}

Water quality parameters are summarized by station in Table 1. Temperatures at time of sampling ranged from 19.7 to $23.4^{\circ} \mathrm{C}, \mathrm{pH} 8.3$ to 8.6 , specific conductance 2,440 to 5,400 $\mu \mathrm{S} / \mathrm{cm}$, and total alkalinity, 444 to $634 \mathrm{mg} / \mathrm{l}$ as $\mathrm{CaCO}_{3}$.

A total of 514 fishes representing six families and 16 species were documented overall (Table 2). Two percids, the Rainbow (Etheostoma caeruleum) and Fantail (E. flabellare) darters were overall dominants representing $63 \%$ of the ichthyofaunal complement, with the Rainbow Darter present at all stations and the Fantail Darter at all but one. Addition of the Greenside Darter (E. blennioides) brings the total dominance of these percids to $70 \%$ (Table 2 ). The two Rainbow Trout (Oncorhynchus mykiss) and one Brown Trout (Salmo trutta) of hatchery origin were excluded from the IBI calculation. Scuds (Gammarus sp.) were the macroinvertebrate dominant representing $70 \%$ of the 803 individual macroinvertebrates representing 18 taxa collected from the entire sampling reach (Table 3). No significant relationship exists between fish and macroinvertebrate taxonomic richness and specific conductance (Figure 2, p-value $>0.05$ ). Fish abundance declined with increasing specific conductance $\left(\mathrm{R}^{2}=0.47\right.$; $\mathrm{p}<0.05)$, while macroinvertebrate communities responded positively $\left(\mathrm{R}^{2}=0.44 ; \mathrm{p}<0.05\right)$ (Figures. 3 and 4 ). Both fish and macroinvertebrate communities exhibited low IBI scores - 20 ("poor") and 41 ("impaired") respectively.

\section{Discussion}

Values of temperature, $\mathrm{pH}$, and total alkalinity fall within acceptable levels according to PA DEP WWF criteria for these parameters [21]. However, background levels of $\mathrm{pH}$ and total alkalinity for a nearby unimpacted reach of Tenmile Creek were 8.0 and $170 \mathrm{mg} / \mathrm{l}$ as $\mathrm{CaCO}_{3}$ respectively. While no regulatory criterion has been developed for specific conductance relative to aquatic life in Pennsylvania, Black [23] recommended a maximum of $400 \mathrm{mg} / \mathrm{l}$ of TDS for sustaining diverse fish populations. Conversion of specific conductance values to TDS values utilizing the 0.65 multiplier [24] for all stations sampled in this study well exceed this maximum. In addition, all stations far exceed the USEPA recommended benchmark of $300 \mu \mathrm{S} / \mathrm{cm}$. In two recent studies of aquatic communities in Tenmile Creek and its South Fork, Kimmel and Argent [17, 18] describe extant fish and macroinvertebrate communities at levels of specific conductance exceeding $1,000 \mu \mathrm{S} / \mathrm{cm}$. These values were attributed to treated mine effluents which elevated stream levels far above the $400 \mu \mathrm{S} / \mathrm{cm}$ background and for the Basin [18] as well as the USEPA benchmark.

The range of specific conductance values recorded in the present study far exceed those encountered in the Tenmile Creek Basin and have negatively impacted aquatic communities here as reflected by the IBI scores. Both fish and macroinvertebrate communities are dominated by taxa tolerant or moderately tolerant to non-specific stressors [25]. Only four individuals representing two of the EPT taxonomic metric of the IBI - (Ephemeroptera and Plecoptera) were collected; and the two Trichoptera taxa, Hydropsyche sp. and Chimarra sp. are listed as having "intermediate" pollution tolerance by the Pennsylvania DEP 
[22]. The fish community was dominated by "tolerant" and "intolerant" taxon present. "intermediate" fishes, with the Greenside Darter the only

Table 1. Water quality parameters measured from Whiteley Creek sampling stations.

\begin{tabular}{lllll}
\hline Site No. & Temp. $\left({ }^{\circ} \mathbf{C}\right)$ & pH & Sp. Cond. $(\boldsymbol{\mu S} / \mathbf{c m})$ & Alkalinity $(\mathbf{m g} / \mathbf{l}$ as CaCo $)$ \\
\hline 1 & 20.2 & 8.5 & 2400 & 444 \\
2 & 20.6 & 8.5 & 3868 & 446 \\
3 & 21.1 & 8.6 & 3961 & 456 \\
4 & 21.6 & 8.6 & 4393 & 470 \\
5 & 19.7 & 8.4 & 3810 & 488 \\
6 & 20.7 & 8.4 & 4218 & 492 \\
7 & 19.7 & 8.3 & 5150 & 598 \\
8 & 20.5 & 8.3 & 5400 & 634 \\
9 & 22.7 & 8.4 & 4020 & 458 \\
10 & 23.4 & 8.4 & 4825 & 578 \\
\hline
\end{tabular}

Table 2. Taxonomic distribution and abundances of the ichthyofauna among Whiteley Creek sampling stations. Salmonids have been excluded from species richness enumeration.

\begin{tabular}{|c|c|c|c|c|c|c|c|c|c|c|c|}
\hline Common Name & Scientific Name & 1 & 2 & 3 & 4 & 5 & 6 & 7 & 8 & 9 & 10 \\
\hline Central Stoneroller & Campostoma anomalum & 8 & 5 & 12 & 1 & 4 & & & 2 & & 6 \\
\hline Bluntnose Minnow & Pimephales notatus & & & & & & & 1 & & & \\
\hline Creek Chub & Semotilus atromaculatus & & & & 1 & & 1 & 1 & & 1 & \\
\hline White Sucker & Catostomus commersonii & 2 & 4 & 1 & & & & 2 & 6 & 3 & \\
\hline Northern Hog Sucker & Hypentelium nigricans & & & 6 & 2 & 3 & & & 1 & 1 & \\
\hline Yellow Bullhead & Ameiurus natalis & & 1 & & & & 1 & 3 & 4 & & 3 \\
\hline Green Sunfish & Lepomis cyanellus & 5 & 6 & 2 & 7 & 1 & 3 & 17 & 8 & 3 & \\
\hline Pumpkinseed & Lepomis gibbosus & & & & & & & 1 & & & \\
\hline Bluegill & Lepomis macrochirus & & & & & 1 & & & 2 & & \\
\hline Smallmouth Bass & Micropterus dolomieu & 1 & & & 1 & & & & & & \\
\hline Rainbow Trout & Oncorhynchus mykiss & & & 2 & & & & & & & \\
\hline Brown Trout & Salmo trutta & & & & & & & & & & 1 \\
\hline Greenside Darter & Etheostoma blennioides & 2 & 5 & 3 & 9 & 7 & 5 & & & 4 & 1 \\
\hline Fantail Darter & Etheostoma flabellare & 23 & 12 & 24 & 9 & 14 & 1 & 4 & & 2 & 1 \\
\hline Total Abundance & & 78 & 66 & 83 & 60 & 42 & 41 & 37 & 30 & 34 & 43 \\
\hline Species Richness & & 8 & 7 & 6 & 9 & 7 & 7 & 8 & 7 & 8 & 5 \\
\hline
\end{tabular}

Table 3. Taxonomic distribution and abundances of macroinvertebrates among Whiteley Creek sampling stations.

\begin{tabular}{|c|c|c|c|c|c|c|c|c|c|c|c|}
\hline Taxa & & 1 & 2 & 3 & 4 & 5 & 6 & 7 & 8 & 9 & 10 \\
\hline Tubificidae & & 1 & & 1 & & & & & & & \\
\hline Physidae & & 6 & & 4 & & & 1 & 8 & & 2 & \\
\hline Gammaridae & Gammarus & 9 & 5 & 10 & 23 & 89 & 19 & 179 & 112 & 66 & 51 \\
\hline Cambaridae & Cambarus & 1 & & & & & & & & & \\
\hline Baetidae & & & & 1 & 1 & & & & & & \\
\hline Leuctridae & Leuctra & & & & & & & & 1 & & \\
\hline Perlidae & Acroneuria & & 1 & & & & & & & & \\
\hline Hydropsychidae & Hydropsyche & 11 & 12 & 5 & 3 & 3 & & 15 & 34 & & 3 \\
\hline Philopotamidae & Chimarra & & 2 & 4 & 2 & 2 & 1 & & & 3 & 14 \\
\hline Gyrinidae & Gyrinus & 3 & 6 & 1 & 4 & 5 & 1 & 2 & 20 & 1 & 4 \\
\hline Psephenidae & Psephenus & & & & & 2 & & & & & \\
\hline Sialidae & Sialis & & & 4 & & 1 & 1 & 1 & & & \\
\hline \multirow[t]{2}{*}{ Corydalidae } & Corydalus & & 2 & 1 & 1 & 4 & 3 & 2 & 3 & 2 & 1 \\
\hline & Nigronia & 1 & & & & & & & & & \\
\hline Athericidae & Atherix & & 2 & 2 & 3 & 2 & 1 & & & 1 & 1 \\
\hline Simulidae & & & 1 & & & & & 1 & & & \\
\hline Tipulidae & & & 1 & & & & & & & & \\
\hline TAXA & & 7 & 9 & 9 & 7 & 8 & 7 & 7 & 6 & 7 & 6 \\
\hline INDIVIDUALS & & 32 & 32 & 33 & 37 & 108 & 27 & 208 & 170 & 75 & 74 \\
\hline
\end{tabular}




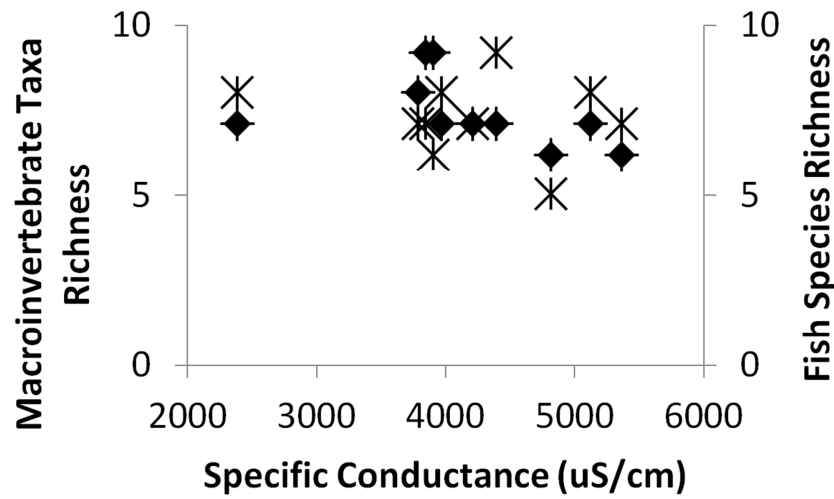

Figure 2. Responses of Whiteley Creek fish and macroinvertebrate taxonomic richness to elevated levels of specific conductance. Asterisks and diamonds denote fish and macroinvertebrates respectively.

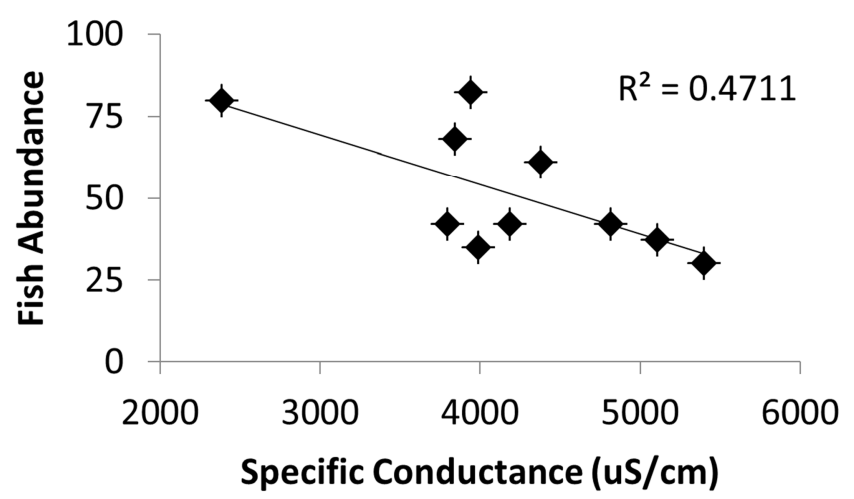

Figure 3. Responses of Whiteley Creek fish abundance to elevated levels of specific conductance.

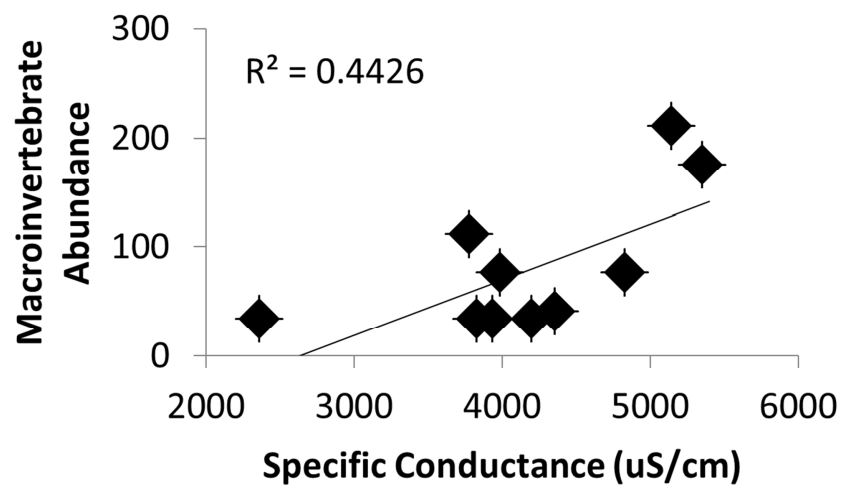

Figure 4. Responses of Whiteley macroinvertebrate abundance to elevated levels of specific conductance.

Elevated specific conductance which increases with increasing TDS can exert osmoregulatory stress on aquatic biota $[26,27,28]$ as well as toxicity from the ionic constituents' present. Toxicity of the mixtures of TDS to aquatic life depends upon the combinations and concentrations of the ions in solution which may produce additive or synergistic effects and is not predictable from TDS or specific conductance [29]. Weber-Scannell and Duffy [30], in a summary of TDS effects on aquatic life from bioassays, report varying responses by species and life stages to mixtures and concentrations of specific ions. The effects of discharges of treated mine effluents on the biota of receiving streams depends on its volume and ionic constituents as well as the assimilative capacity of the receiving water.

\section{Conclusion}

Here we describe the structures of resident fish and macroinvertebrate communities of a stream exhibiting elevated levels of specific conductance resulting from treated AMD effluent. Both communities exhibited low bioassessment metric scores and suggest the importance of biomonitoring and bioassessment of streams receiving effluents from active treatment of AMD.

\section{Acknowledgements}

Mr. Austin Hess is acknowledged for his assistance with field sampling and the Faculty Professional Development Fund of California University of Pennsylvania for underwriting this work.

\section{References}

[1] Pennsylvania Department of Environmental Protection (PA DEP) (1999). The science of acid mine drainage and passive treatment. PA DEP Publication, Bureau of Abandoned Mine Reclamation, Harrisburg, Pennsylvania.

[2] Scott, R. L. and R. M. Hays (1975). Inactive and abandoned underground mines - water pollution prevention and control. U.S. EPA - 440/9-75-007. U.S. Environmental Protection Agency; Office of Water; Washington, D. C.

[3] Rose, A. W. and C. A. Cravotta, III (1998). Geochemistry of coal mine drainage. Coal Mine Drainage Prediction and Pollution Prevention in Pennsylvania. Pennsylvania Department of Environmental Protection, Harrisburg, Pennsylvania.

[4] Butler, R. L., E. L. Cooper, D. C. Hales, C. C. Wagner, W. G. Kimmel, and J. K. Crawford (1973). Fish and food organisms in acid mine waters of Pennsylvania. Office of Research and Monitoring, EPA-R-73-032. U.S. Environmental Protection Agency, Washington, D. C.

[5] W. G. Kimmel (1983). The impact of acid mine drainage on the stream ecosystem. In S. K. Majumdar \& Miller, E. W. (Eds.), Pennsylvania coal: resources, technology and utilization. Pennsylvania Academy of Science, Easton, Pennsylvania.

[6] Kimmel, W. G., C. A. Miller, and T. C. Moon (1981). The impact of a deep-mine drainage on the water quality and biota of a small hard-water stream. Proceedings of the Pennsylvania Academy of Science 55, 137-141.

[7] Kimmel, W. G., and D. G. Argent (2006). Development and application of an index of biotic integrity (IBI) for fish communities of wadeable Monongahela River tributaries. Journal of Freshwater Ecology 21 (2), 183-190.

[8] R. Ventorini (2002). Fish community in warmwater tributaries of the Youghiogheny River impacted by net alkaline deep mine discharges. MS Thesis. California University of Pennsylvania, California, Pennsylvania, 57. 
[9] Knuth, M., J. L. Jackson, and D. O. Whittemore (2005). An integrated approach to identifying the salinity source contaminating a ground-water supply. Groundwater 28 (2), 207-214.

[10] Short, T. M., J. A. Black, and W. Burge (1991). Ecology of a saline stream: community responses to spatial gradients of environmental conditions. Hydrobiologia 226 (3), 167-178.

[11] United States Environmental Protection Agency (USEPA) (2009). Update on Dunkard Creek. US EPA Region 3, Environmental Analysis and Innovation Division, Office of Monitoring and Assessment, Wheeling, West Virginia.

[12] United States Environmental Protection Agency (USEPA) (2011). A field-based aquatic life benchmark for conductivity in Central Appalachian Streams. National Center for Environmental Assessment. Office of Research and Development, Cincinnati, OH. EPA/600/R-10/023F.

[13] Skousen, J. K., K. Politan, T. Hilton, and A. Meeks (1990). Acid mine drainage treatment systems: chemicals and costs. Green Lands 20 (4), 31-37.

[14] J. K. Skousen (N. D.). Overview of acid mine drainage treatment with chemicals. West Virginia University, Morgantown, West Virginia.

$<$ http://anr.ext.wvu.edu/r/download/118382; Accessed December 9, 2016.>

[15] R. S. Hedin (1989). Treatment of coal mine drainage with constructed wetlands. In S. K. Majumdar, Brooks, R. P., Breener, F. J., \& Tiner, R. W. Wetlands Ecology and Conservation: Emphasis in Pennsylvania. Pennsylvania Academy of Science, Easton, Pennsylvania.

[16] Hedin, R. S., G. R. Watzlaf, and R. W. Nairn (1994). Passive treatment of acid mine drainage with limestone. Journal of Environmental Quality 23, 1338-1345.

[17] Kimmel, W. G., and D. G. Argent (2010). Stream fish community responses to a gradient of specific conductance. Water, Air, and Soil Pollution 206 (1), 49-56.

[18] Kimmel, W. G., and D. G. Argent (2012). Status of fish and macroinvertebrate communities in a watershed experiencing high rates of fossil fuel extraction: Tenmile Creek, a major Monongahela River tributary. Water, Air, and Soil Pollution 223 (7), 4647-4657.

[19] Kennedy, A. J., D. S. Cherry, and R. J. Currie (2003). Field and laboratory assessment of a coal processing effluent in the Leading Creek Watershed, Meigs County, Ohio. Archives of Environmental Contamination and Toxicology 44 (3), 324331.
[20] Pond, G. J., M. E. Passamore, F. A. Borsuk, and C. J. Rose (2008). Downstream effects of mountaintop coal mining: Comparing biological conditions using family- and genuslevel macroinvertebrate bioassessment tools. Journal of the North American Benthological Society 27 (3), 717-737.

[21] Pennsylvania Department of Environmental Protection (PA DEP) (2001). Commonwealth of Pennsylvania, Pennsylvania Code, Title 25. Environmental Protection. Harrisburg, Pennsylvania.

[22] B. A. Chalfant (2015). An index of biotic integrity for benthic macroinvertebrate communities in Pennsylvania's wadeable, freestone, riffle-run streams. Pennsylvania Department of Environmental Protection, Bureau of Clean Water, Harrisburg, Pennsylvania.

[23] J. A. Black (1977). Water pollution technology. Reston Publishing Company, Inc. Reston, Virginia.

[24] Rainwater, F. H., and L. L. Thatcher (1960). Methods for collection and analysis of water samples. U.S. Geological Water Supply Paper 1454. U.S. Government Printing Office, Washington, D. C.

[25] Barbour, M. T., J. Gerritsen, B. D. Snyder, and J. B. Stribling (1999). Rapid bioassessment protocols for use in streams and wadeable rivers: periphyton, benthic macroinvertebrates and fish, second edition. EPA 841-B-99-002. U.S. Environmental Protection Agency; Office of Water; Washington, D. C.

[26] J. Bailey (2009). Watershed assessment section's 2009 standard operating procedures. Charleston: West Virginia Department of Environmental Protection, Division of Water and Waste Management, Watershed Branch.

[27] D. H. Evans (2008). Teleost fish osmoregulation: what have we learned since August Krogh, Homer Smith, and Ancel Keys. American Journal of Physiology - Regulatory. Integrative and Comparative Physiology, 295 (2), R704-R713, doi: 10.1152/ajpregu.90337.200.

[28] Wood, C. M., and T. J. Shuttleworth (2008). Cellular and molecular approaches to fish ionic regulation. Vol. 14: Fish physiology. Academic, San Diego, California.

[29] Chapman, P. M., H. Bailey, and E. Canaria (2000). Toxicity of total dissolved solids associated with two mine effluents to chironomid larvae and early life stages of rainbow trout. Environmental Toxicology and Chemistry 19 (1), 210-214.

[30] Weber-Scannell, P. K., and L. K. Duffy (2007). Effects of total dissolved solids on aquatic organisms: a review of literature and recommendation for salmonid species. American Journal of Environmental Sciences 3 (1), 1-6. 